\title{
RANCANG BANGUN SISTEM PENYEMPROT TANAMAN OTOMATIS BERDASARKAN WAKTU DENGAN REAL TIME CLOCK (RTC) DAN SENSOR ULTRASONIK SERTA NOTIFIKASI VIA SMS
}

\author{
Nia Sulfiani R, Nini Firmawati* \\ Jurusan Fisika, FMIPA, Universitas Andalas, Limau Manis, Padang, 25163 \\ *Korespondensi ke: firmawatinini@gmail.com
}

( Diterima:04 Juli 2019; Direvisi: 24 Juli 2019; Diterbitkan: 01 September 2019 )

\begin{abstract}
ABSTRAK
Telah dirancang sistem penyemprot tanaman otomatis berdasarkan waktu dengan Real Time Clock (RTC) dan sensor ultrasonik serta notifikasi via SMS. Sistem ini berfungsi untuk menyiram tanaman secara otomatis berdasarkan waktu yang telah diatur pada program dan sistem akan memberikan informasi kepada pengguna saat air dalam wadah habis. Sistem terdiri dari RTC DS3231 sebagai penghitung waktu, satu buah relai sebagi saklar, pompa air mini untuk menyemprot tanaman, sensor ultrasonik HC-SR04 untuk mendeteksi ketinggian air, GSM SIM 800L untuk mengirim SMS sebagai peringatan kepada pengguna dan LCD untuk menampilkan jarak dan waktu. Sistem ini bekerja berdasarkan waktu sedemikian rupa sehingga pompa air hidup pada saat pukul 08.00 WIB dan pukul 17.00 WIB. Pada waktu yang sama ketinggian air dalam wadah dideteksi sensor ultrasonik, jika jarak air dengan sensor $25 \mathrm{~cm}$ maka peringatan kepada pengguna berupa SMS "air hampir habis" dikirim oleh GSM. Berdasarkan hasil uji sistem jarak GSM yang digunakan dengan lokasi penerima SMS tidak berpengaruh, rata- rata waktu yang didapatkan untuk lima variasi jarak pengiriman yaitu 7,876 s, 8,646 s, 8,824 s, dan 8,676 s. Sistem penyiram tanaman otomatis ini dikontrol dengan modul Arduino Uno.

Kata kunci: Arduino Uno, GSM SIM 800L, RTC DS3231, Sistem penyemprot otomatis, Ultrasonik HC-SR04.
\end{abstract}

\begin{abstract}
The automatic plant sprayer system based on time with real time clock (RTC) and ultrasonic sensor via short message service notification. The function of this system was to spray the plant automatically based on the time that has been set in the program. The system will be informed to the user when the water in the gallon was empty. This system consists from RTC as a timer, a relay as a switch, mini water pump to spray the plant, Ultrasonic sensor to detect the level of water, GSM to send SMS as a warning to the user, and the LCD to display the time and distance. This system work based on the time when the water pump turned on at 08.00 AM and 17.00. in the same time, the level of water will be detected by ultrasonic sensor, if the distance between water and sensor was $25 \mathrm{~cm}$, the warning to the user will be sent via SMS (the water will be filled out). Based on the system, the data result of GSM sensor that will be used between SMS receiver, the time average with five times in variation was 7,876 s, 8,646 s, 8,824 s, and 8,676 s. This automatically plant sprayer water was controlled with Arduino as board modul.
\end{abstract}

Keywords: Arduino Uno, GSM SIM 800L, RTC DS3231, Automatic spraying system, Ultrasonic HC-SR04. 


\section{PENDAHULUAN}

Pertanian merupakan salah satu sektor yang sangat penting bagi masyarakat Indonesia. Sebagian penduduk Indonesia menjadikan pertanian sebagai mata pencaharian, sehingga Indonesia disebut negara agraris (Rohaida, 2014). Salah satu jenis tanaman yang dibudidayakan petani di Indonesia yaitu sayur-sayuran. Sayur-sayuran sangat penting bagi kehidupan sehari-hari, yaitu sebagai sumber gizi dalam kesehatan. Tanaman sayuran merupakan jenis komoditi yang memiliki nilai ekonomi tinggi dan berperan penting sebagai salah satu sumber penghasilan bagi petani, sehingga kualitas sayuran sangat penting untuk dijaga (Ningsih dkk, 2016). Untuk mendapatkan kualitas sayuran yang bagus, ada beberapa faktor yang perlu diperhatikan.

Salah satu faktor yang memengaruhi kualitas sayuran yaitu banyaknya Organisme Pengganggu Tanaman (OPT) (Sudiono dkk, 2017). Permasalahan ini merupakan kendala utama dalam peningkatan dan ketahanan tanaman pangan. Hal ini dapat menyebabkan kerugian yang cukup besar baik berupa kehilangan hasil, penurunan mutu, terganggunya kontinuitas produksi, serta penurunan pendapatan petani (Cahyono dan Nurmahaludin, 2015). Organisme Pengganggu Tanaman (OPT) yang paling banyak menyerang sayuran yaitu ulat grayak. Contoh tanaman yang diserang oleh ulat grayak adalah bawang merah. Ulat ini akan memakan daun sehingga terbentuk lubang-lubang pada daun bawang. Daun yang dimakan ulat akan memengaruhi besarnya umbi bawang. Hal ini berkaitan dengan proses fotosintesis (Haryati dan Nurawan, 2009). Tanaman lain yang dimakan ulat yaitu tanaman bayam (Ajiningrum dan Pramushinta, 2017) dan tanaman kubis (Kristanto dkk, 2013) serta berbagai tanaman lainnya. Salah satu upaya pencegahan yang dilakukan petani yaitu dengan melakukan penyemprotan pestisida, namun kegiatan penyemprotan yang dilakukan petani ini dapat menyebabkan efek negatif terhadap petani itu sendiri. Menurut Kurniasih dkk (2018) tenaga kerja petani holtikultural adalah salah satu populasi yang berisiko untuk mengalami keracunan pestisida. Hal ini berkaitan dengan keterlibatan mereka saat penyemprotan tanaman. Salah satu penyakit yang dapat ditimbulkan dari keracunan pestisida ini yaitu anemia yang akan mengakibatkan penderita mudah lelah, lemah, energi tidak memadai sehingga produktivitas petani yang menderita anemia tersebut akan menurun. Dari permasalahan di atas, maka perlu dirancang alat yang dapat membasmi hama pada sayuran secara otomatis agar hasil pertanian sayuran meningkat tanpa harus menyebabkan kerugian pada kesehatan petani.

Beberapa alat penyemprotan tanaman secara otomatis telah dibuat. Fiqhi dkk (2017) telah membuat alat berbasis mikrokontroler Arduino yang dapat memberikan larutan nutrisi kepada tanaman dengan menggunakan satu buah mesin pompa air yang dapat diaktifkan melalui SMS. Ketika pengguna memberikan perintah berupa SMS, maka akan diproses oleh Arduino sehingga pompa air akan aktif menyiram sebanyak 120 kali dalam 1 jam. Alat ini menggunakan RTC (Real Time Clock) yang berfungsi untuk memberikan informasi waktu sehingga pompa air dapat aktif secara otomatis pada waktu yang telah diatur melalui program Arduino. Hansen dkk (2018) telah membuat alat penyemprotan tanaman otomatis menggunakan mikrokontroler Arduino Uno. Alat ini menggunakan Real Time Clock (RTC) yang digunakan untuk mengatur waktu, dengan adanya pengaturan waktu maka pengguna dapat mengatur jadwal penyemprotan, sehingga pompa dapat menyiram tanaman secara otomatis. Alat ini juga dilengkapi dengan sensor air hujan, jika terdeteksi hujan maka alat akan menampilkan notifikasi pada LCD. Dengan demikian pengguna dapat menonaktifkan alat terlebih dahulu. 
Berdasarkan alat yang telah dirancang sebelumnya masih terdapat kelemahan. Kelemahan penelitian sebelumnya yaitu belum dapat memberikan informasi kepada pengguna saat air dalam wadah hampir habis, oleh karena itu maka perlu dirancang suatu alat penyemprotan otomatis pada tanaman berdasarkan waktu kebiasaan petani dalam menyiram tanaman. Alat juga dapat memberikan informasi kepada petani saat air dalam wadah sudah hampir habis. Waktu yang diatur pada program yaitu pukul 08.00 WIB dan pukul 17.00 WIB. Hal ini sesuai dengan anjuran waktu penyemprotan yang baik yaitu pagi antara pukul 08.00 WIB - 11.00 WIB dan sore pukul 15.00 WIB - 18.00 WIB. Sedangkan kebiasaan waktu menyemprot pestisida terlalu pagi atau terlalu sore akan mengakibatkan tanaman keracunan, hal ini karena pestisida yang menempel pada daun terlalu lama mengering (Wudianto, 2005).

Alat yang telah dibuat dipasang Real Time Clock (RTC) yang berfungsi untuk mengatur waktu kerja alat. RTC ini dihubungkan dengan Arduino Uno sebagai alat kontrol. Wadah air yang digunakan pada penelitian ini yaitu sebuah galon. Pada program diatur waktu kerja alat yaitu pukul 08.00 WIB dan pukul 17.00 WIB. Saat RTC menunjukkan pukul 08.00 dan pukul 17.00 WIB, maka pompa air akan menyemprotkan air ke arah tanaman. Durasi penyemprotan air ini berlangsung selama 2 detik untuk luas wadah yang disemprot seluas $15 \mathrm{~cm} \times 15 \mathrm{~cm}$. Saat air dalam wadah habis, maka alat akan menginformasikan kepada pengguna melalui Short Message Service (SMS) dengan modul GSM. Waktu dan jarak sensor ultrasonik dengan air juga akan ditampilkan pada LCD.

\section{METODE PENELITIAN}

\subsection{Bahan dan Alat Penelitian}

Alat yang digunakan dalam penelitian ini yaitu sensor ultrasonik HC-SR04, GSM SIM 800L dan LCD, RTC DS3231, relai, pompa air mini. Bahan yang digunakan yaitu air.

\subsection{Perancangan Diagram Blok Sistem}

Rancangan sistem ini terdiri dari RTC DS3231 sebagai penghitung waktu, satu buah relai sebagi saklar, pompa air mini untuk menyemprot tanaman, sensor ultrasonik HC-SR04 untuk mendeteksi ketinggian air, GSM SIM 800L untuk mengirim SMS sebagai peringatan kepada pengguna dan LCD untuk menampilkan jarak dan waktu. Diagram blok dari rangkaian sistem ini dapat dilihat pada gambar 1

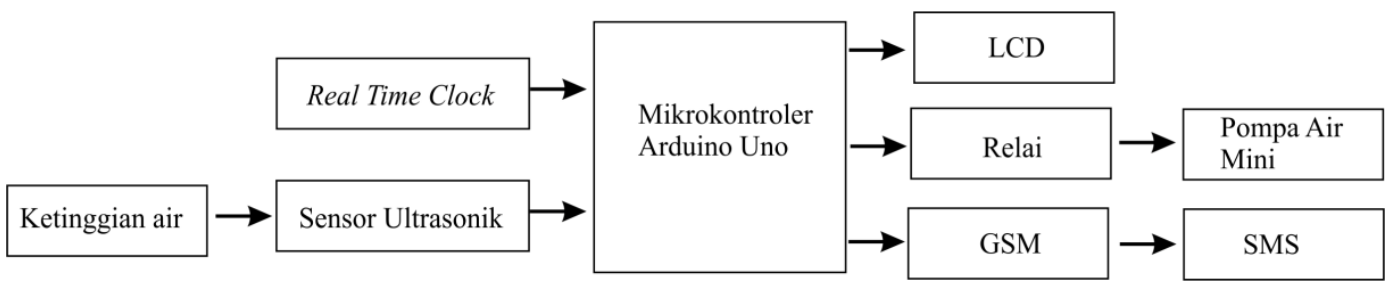

Gambar 1. Perancangan Diagram Blok Sistem.

\subsection{Perancangan Perangkat Lunak}

Program pada mikrokontroler Arduino Uno dibuat dengan bahasa C. Diagram alir program pengontrolan sistem dapat dilihat pada Gambar 2 


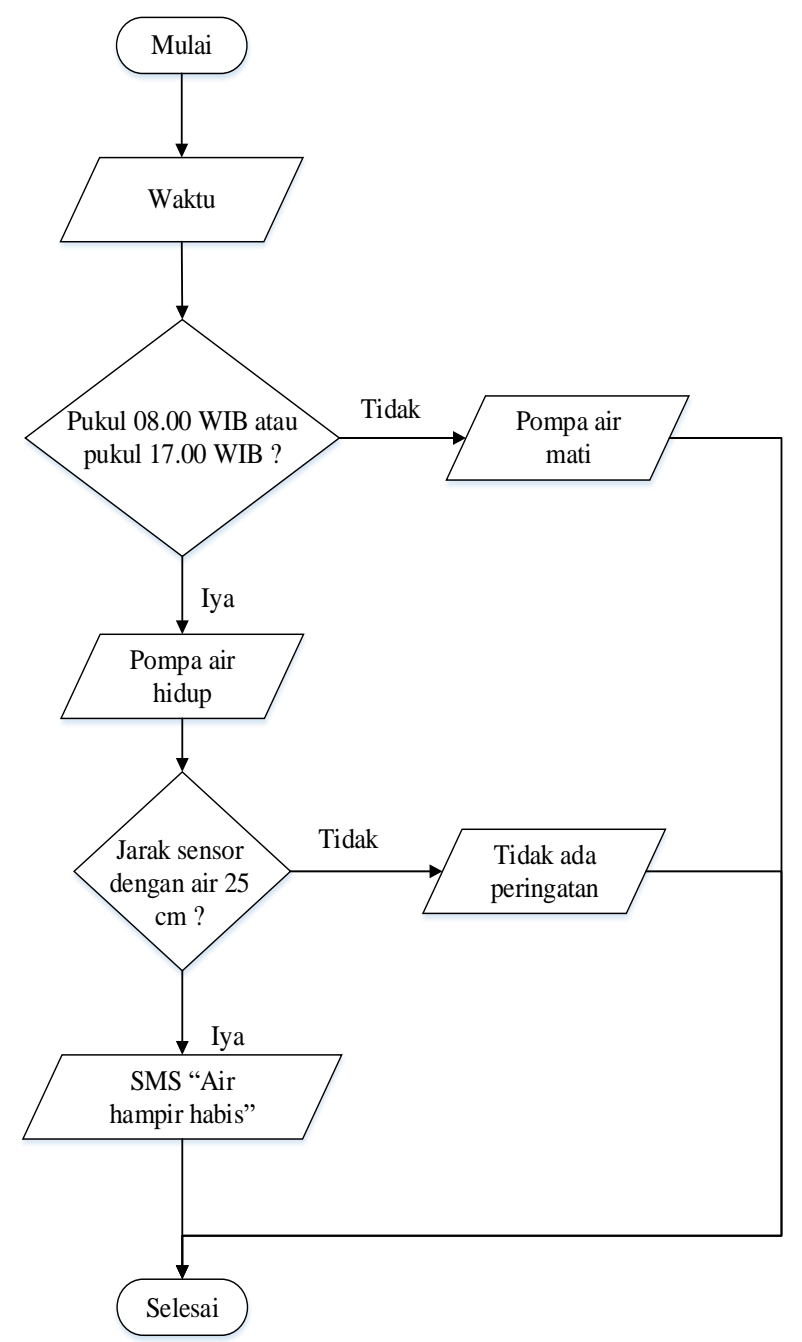

Gambar 2. Diagram Alir Program Pengontrol Sistem

Diagram alir pada Gambar 2 menunjukkan proses kerja alat pembasmi hama pada tanaman secara otomatis. Pada awal program akan dilakukan inisialisasi program. Pada proses ini diberi data masukan berupa waktu yang akan dihitung oleh RTC. Data masukan akan diteruskan ke mikrokontroler untuk diproses. Proses pada penelitian ini yaitu sebagai berikut:

1. RTC akan menghitung waktu dan akan diatur pada program sebagai data masukan. Saat waktu yang diatur menunjukkan pukul 08.00 WIB atau pukul 17.00 WIB maka pompa air akan hidup. Penyiraman hanya berlangsung selama 2 detik.

2. Apabila sensor ultrasonik HC-SR04 pada wadah yang berisi air mendeteksi air sejauh $25 \mathrm{~cm}$ dari sensor maka modul GSM/GPRS SIM800L akan mengirim SMS ke pengguna dengan mengatakan "air hampir habis". Jika jarak permukaan air dari sensor ultrasonik HC-SR04 yang terdeteksi kurang dari $25 \mathrm{~cm}$, maka tidak ada peringatan.

\subsection{Perancangan Sistem Keseluruhan}

Sistem keseluruhan yang dibuat merupakan sebuah sistem yang dapat bekerja secara otomatis. Sistem ini dapat bekerja secara otomatis dengan dikontrol Arduino Uno yang terhubung dengan Real Time Clock (RTC), sensor ultrasonik, GSM, LCD dan relai. GSM 
digunakan untuk menghubungi pengguna saat air dalam wadah sudah habis. Rangkaian sistem keseluruhan dapat dilihat pada gambar 3

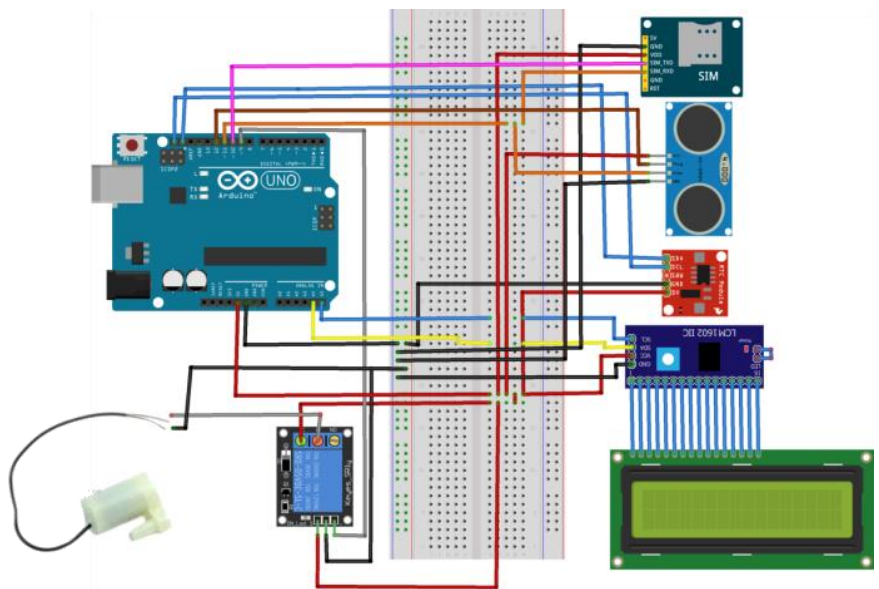

Gambar 3. Rangkaian Sistem Keseluruhan

\section{HASIL DAN DISKUSI}

\subsection{Hasil Perancangan Sistem Keseluruhan}

Telah dilakukan karakterisasi pada sensor ultrasonik dan GSM SIM800L untuk mengetahui komponen yang digunakan pada alat yang dirancang dapat berfungsi dengan baik atau tidak. Hasil yang didapat pada setiap pengujian alat dibandingkan dengan landasan teori yang berhubungan dengan perangkat yang digunakan. Gambar rangkaian keseluruhan dapat dilihat pada gambar 4

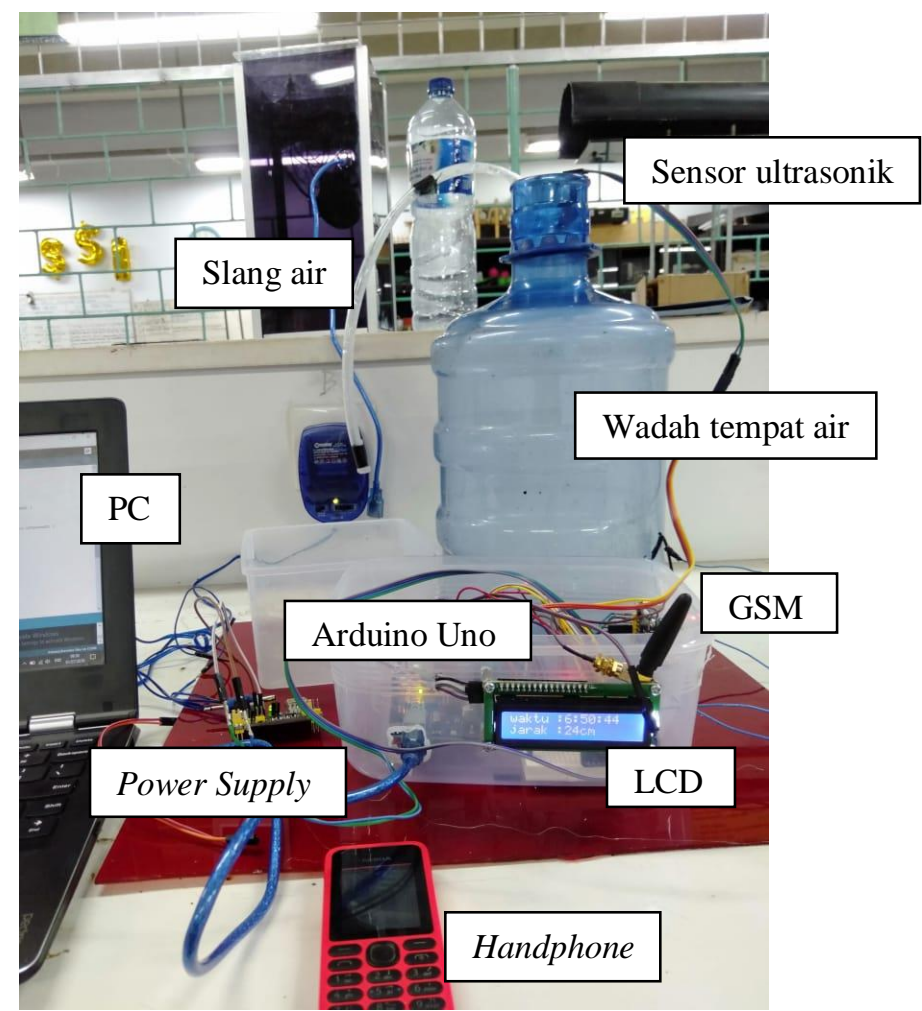

Gambar 4. Pengujian Akhir Rangkaian Keseluruhan 


\subsection{Hasil Pengujian Sensor Ultrasonik}

Sensor ultrasonik pada penelitian ini digunakan untuk mendeteksi ketinggian air dalam wadah. Pengujian sensor ultrasonik dilakukan dengan mendeteksi ketinggian air yang berada di dalam wadah setinggi $30 \mathrm{~cm}$ dengan variasi jarak $5 \mathrm{~cm}$. Waktu akan dihitung setiap jarak $5 \mathrm{~cm}$. Penghitungan waktu dapat dilihat pada program yang telah ditanamkan kedalam mikrokontroler Arduino dengan software Arduino IDE. Hasil pengujian ini dapat dilihat pada tabel 1

Tabel 1 Hasil pengujian sensor ultrasonik

\begin{tabular}{cc}
\hline Jarak $(\mathbf{c m})$ & Waktu $(\boldsymbol{\mu s})$ \\
\hline 5 & 317 \\
10 & 606 \\
15 & 882 \\
20 & 1176 \\
25 & 1497 \\
30 & 1790 \\
\hline
\end{tabular}

Dari hasil pengujian di atas dapat dilihat bahwa semakin jauh jarak sensor ultrasonik dengan air maka waktu yang dibutuhkan gelombang yang dipancarkan untuk sampai kembali ke sensor ultrasonik semakin besar. Grafik hasil pengukuran pada tabel 1 dapat dilihat pada Gambar 5

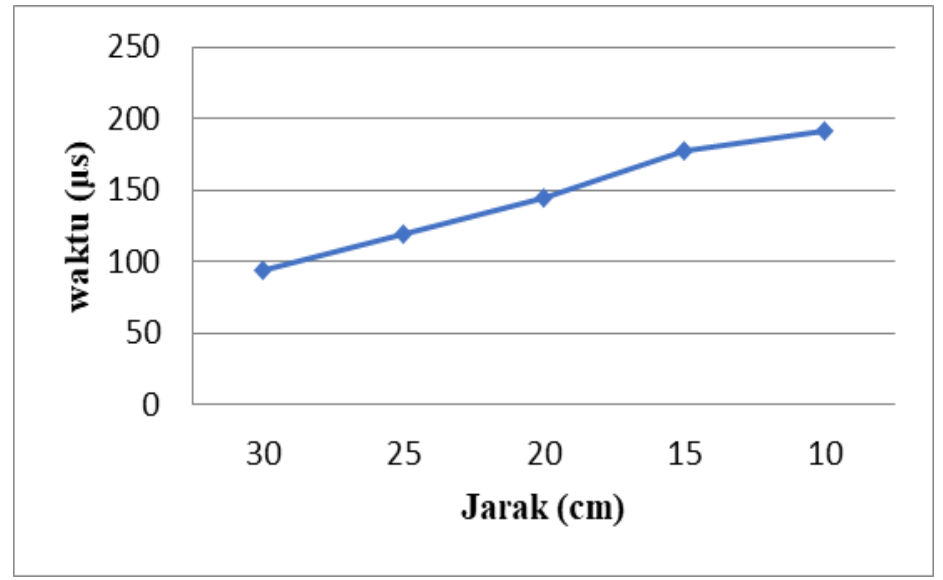

Gambar 5 Grafik Hasil Pengujian Sensor Ultrasonik

\subsection{Hasil Pengujian Real Time Clock (RTC)}

Real Time Clock (RTC) pada penelitian ini berfungsi untuk mengatur waktu berupa hari, tanggal, jam, menit dan detik. Pengujian RTC berfungsi untuk mengetahui apakah RTC yang digunakan sudah dapat berfungsi dengan baik. Hasil Pengujian rangkaian RTC dapat dilihat pada gambar 6 . 


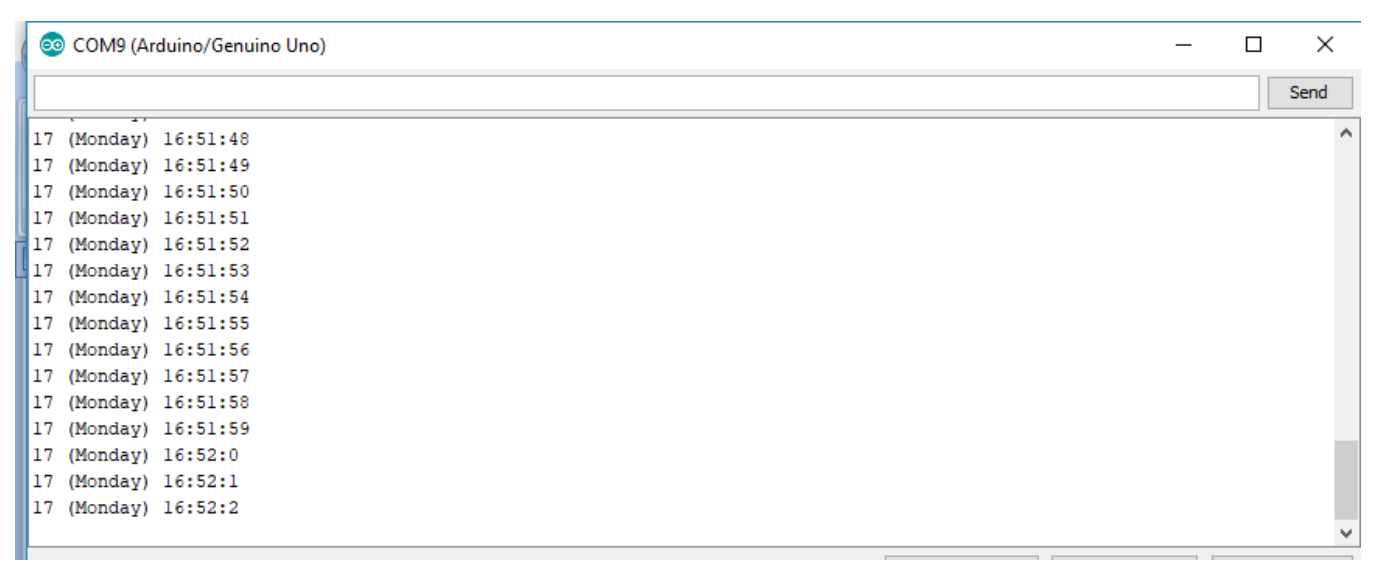

Gambar 6 Hasil Pengujian RTC

\subsection{Hasil Pengujian SIM GSM800L}

Pengujian modul SIM 800L bertujuan untuk mengetahui apakah modul ini dapat berfungsi dengan baik. Modul SIM 800L pada penelitian ini berfungsi untuk mengirimkan SMS kepada pengguna saat air dalam wadah habis. Hasil run program dapat dilihat pada gambar 7

\begin{tabular}{|c|c|c|c|c|c|c|}
\hline \multirow{2}{*}{ (6) $\operatorname{com} 9$ (Arduino/Genuino Uno) } & & & & \multirow[t]{2}{*}{-} & \multirow[t]{2}{*}{$\square$} & $x$ \\
\hline & & & & & & Send \\
\hline \multicolumn{7}{|l|}{$\begin{array}{l}\text { GPRS-Send SMS Test } \\
\text { program succes }\end{array}$} \\
\hline
\end{tabular}

Gambar 7 Hasil run program GPRS

\subsubsection{Pengujian Jarak $0,1 \mathrm{~m}$}

Pengujian pertama dilakukan pada jarak $0,1 \mathrm{~m}$. Pengujian ini dilakukan pada lokasi pertama yaitu di Laboratorium Elektronika dan Instrumentasi Jurusan Fisika Universitas Andalas. HP pengguna yang dijadikan untuk menerima pesan, berada $0,1 \mathrm{~m}$ dari modul SIM 800L.

Tabel 2. Pengujian GSM SIM 800L jarak $0,1 \mathrm{~m}$

\begin{tabular}{cc}
\hline Percobaan ke- & $\begin{array}{c}\text { Waktu Pengiriman SMS } \\
\text { sampai SMS diterima(s) }\end{array}$ \\
\hline 1 & 8,85 \\
2 & 7,93 \\
3 & 6,88 \\
4 & 8,10 \\
5 & 7,89 \\
\hline Waktu rata-rata & 7,876 \\
\hline
\end{tabular}




\subsubsection{Pengujian Jarak $1.400 \mathrm{~m}$}

Pengujian kedua dilakukan pada jarak $1.400 \mathrm{~m}$. Pengujian ini dilakukan di Laboratorium Elektronika dan Instrumentasi Jurusan Fisika Universitas Andalas. Lokasi penerima SMS berada di Jurusan Teknik Industri Universitas Andalas.

Tabel 3. Pengujian GSM SIM 800L jarak $1.400 \mathrm{~m}$

\begin{tabular}{cc}
\hline Percobaan ke- & $\begin{array}{c}\text { Waktu Pengiriman SMS } \\
\text { sampai SMS diterima(s) }\end{array}$ \\
\hline 1 & 8,50 \\
2 & 8,91 \\
3 & 8,89 \\
4 & 8,48 \\
5 & 8,45 \\
\hline Waktu rata-rata & 8,646 \\
\hline
\end{tabular}

\subsubsection{Pengujian Jarak $310.000 \mathrm{~m}$}

Pengujian ketiga dilakukan pada jarak $310.000 \mathrm{~m}$. Pengujian ini dilakukan di Laboratorium Elektronika dan Instrumentasi Jurusan Fisika Universitas Andalas. Lokasi penerima SMS berada di Jl.Soekarno-Hatta No.28, Delima, Tampan, Kota Pekan Baru, Riau.

Tabel 4. Pengujian GSM SIM 800L jarak $310.000 \mathrm{~m}$

\begin{tabular}{cc}
\hline Percobaan ke- & $\begin{array}{c}\text { Waktu Pengiriman SMS } \\
\text { sampai SMS diterima(s) }\end{array}$ \\
\hline 1 & 9,00 \\
2 & 8,61 \\
3 & 9,72 \\
4 & 8,26 \\
5 & 8,47 \\
\hline Waktu rata-rata & 8,824 \\
\hline
\end{tabular}

\subsubsection{Pengujian Jarak $1.487 .000 \mathrm{~m}$}

Pengujian keempat dilakukan pada jarak $1.487 .000 \mathrm{~m}$. Pengujian ini dilakukan di Laboratorium Elektronika dan Instrumentasi Jurusan Fisika Universitas Andalas. Lokasi penerima SMS berada di Jl.Cisitu lama No.25 A, Dago, Kota Bandung, Jawa Barat.

Tabel 5. Pengujian GSM SIM 800L jarak $1.487 .000 \mathrm{~m}$

\begin{tabular}{cc}
\hline Percobaan ke- & $\begin{array}{c}\text { Waktu Pengiriman SMS } \\
\text { sampai SMS diterima(s) }\end{array}$ \\
\hline 1 & 9,30 \\
2 & 8,60 \\
3 & 8,48 \\
4 & 8,20 \\
5 & 8,80 \\
\hline Waktu rata-rata & 8,676 \\
\hline
\end{tabular}

Berdasarkan lima kali pengujian GSM SIM 800L yang telah dilakukan pada empat lokasi yang berbeda, waktu rata-rata yang diperoleh hampir sama. Lokasi yang pertama yang berada pada jarak $0,1 \mathrm{~m}$ dari lokasi pengiriman memiliki waktu rata-rata pengiriman $7,876 \mathrm{~s}$, lokasi yang kedua berjarak $1.400 \mathrm{~m}$ memiliki waktu rata-rata 8,646 s, lokasi yang ketiga berjarak $310.000 \mathrm{~m}$ memiliki waktu rata-rata $8,824 \mathrm{~s}$, dan lokasi keempat yang berjarak $1.487 .000 \mathrm{~m}$ memiliki waktu rata-rata 8,676 $\mathrm{s}$. Berdasarkan hasil tersebut, dapat 
disimpulkan bahwa jarak tidak mempengaruhi waktu pengiriman SMS dengan GSM SIM $800 \mathrm{~L}$.

\subsection{Pengujian Sistem Secara Keseluruhan}

Pengujian ini dilakukan dengan menghubungkan semua komponen seperti sensor ultrasonik, RTC, GSM SIM 800L, relai, serta LCD. Selanjutnya program yang telah diuji untuk masing-masing komponen akan digabungkan. Program keseluruhan yang telah tercompile selanjutnya di-upload ke rangkaian keseluruhan. Pengujian sistem keseluruhan dilakukan dalam 6 waktu dapat dilihat pada tabel 6

Tabel 6. Pengujian sistem keseluruhan

\begin{tabular}{cccc}
\hline Pukul & $\begin{array}{c}\text { Keterangan } \\
\text { Pompa }\end{array}$ & $\begin{array}{c}\text { Jarak sensor ultrasonik } \\
\text { dengan air }(\mathbf{c m})\end{array}$ & $\begin{array}{c}\text { Keterangan } \\
\text { peringatan }\end{array}$ \\
\hline 16.59 .00 & $O F F$ & 23 & Tidak ada \\
17.00 .00 & $O N$ & 24 & Tidak ada \\
17.00 .03 & $O F F$ & 24 & Tidak ada \\
07.59 .00 & $O F F$ & 24 & Tidak ada \\
08.00 .00 & $O N$ & 25 & Ada \\
\hline
\end{tabular}

\section{KESIMPULAN}

Berdasarkan pengujian dan analisa yang telah dilakukan, maka didapatkan kesimpulan bahwa rancang bangun sistem penyemprot tanaman otomatis berdasarkan waktu dengan real time clock (RTC) dan sensor ultrasonik serta notifikasi via SMS telah berhasil dilakukan. Relai dapat mematikan dan menghidupkan pompa air secara otomatis berdasarkan waktu yang telah diatur pada program yaitu pukul 08.00 WIB dan pukul 17.00 WIB. GSM SIM 800L telah dapat mengirimkan SMS kepada nomor handphone yang telah dicantumkan pada program jika sensor ultrasonik telah mendeteksi ketinggian air sejauh $25 \mathrm{~cm}$.

\section{UCAPAN TERIMA KASIH}

Ucapan terimakasih kepada Jurusan Fisika FMIPA Universitas Andalas dan Laboratorium Instrumentasi dan Elektronika Jurusan Fisika FMIPA Universitas yang telah memfasilitasi penelitian ini.

\section{DAFTAR PUSTAKA}

Ajiningrum, \& Pramushinta. (2017). Pengaruh pemberian konsentrasi bioinsektisida daun dan biji mimba (Azadirachta Indica) terhadap kematian ulat grayak (Spodoptera Litura), Stigma, 2, 74-79.

Cahyono, G. R., \& Nurmahaludin. (2017). Rancang bangun alat perangkap hama tanaman padi menggunakan Arduino Mega 2560. Jurnal Poros Teknik, 2, 54-105.

Fiqhi, A., Yani, P., \& Grace G. (2017). Sistem aeroponik berbasis Arduino Uno dan komunikasi GSM untuk pemberian larutan nutrisi untuk budidaya sayuran. Jurnal Resti, 2, 153-159.

Hansen, D., Genrawan, H., \& Lina. (2017). Perancangan perangkat penyiram tanaman otomatis menggunakan mikrokontroler Arduino Uno. Jurnal Inteksis, 2, 64-75.

Haryati, Y. \& Nurawan, A. (2009). Peluang pengembangan feromon seks dalam pengendalian hama ulat bawang (Spodoptera Exigua) pada bawang merah. Jurnal Litbang Pertanian, 2, 72-77. 
Kristanto, S. P., Sutjipto, \& Soekarto. (2013). Pengendalian hama pada tanaman kubis dengan sistem tanam tumpangsari. Jurnal Berkala Ilmiah Pertanian, 1, 7-9.

Kurniasih, S. A., Onny, S., \& Sri, A. N. (2013). Faktor-faktor yang terkait paparan pestisida dan hubungannya dengan kejadian anemia pada petani hortikultura di Desa Gombong Kecamatan Belik Kabupaten Pemalang Jawa Tengah. Jurnal Kesehatan Lingkungan Indonesia, 2, 132-137.

Ningsih, S., Yusmini, \& Eliza. (2016). Analisis kontribusi pendapatan usahatani sayuran daun terhadap pendapatan rumah tangga. Indonesian Journal of Agricultural Economics (IJAE), 2, 1-12.

Rohaida, I. S. (2014). Pemanfaatan lahan dengan menggunakan sistem hidroponik. Jurnal Universitas Tulungagung Bonorowo, 2, 43-50.

Sudiono, Surjono, H. S., Nurheni, W., Purnama, H., \& Rachman, K. (2016). Analisis berkelanjutan usahatani tanaman sayuran berbasis pengendalian hama terpadu di Kabupaten Tanggamus Provinsi Lampung. J. Hort, 2, 297-310.

Widianto, R. (2005). Petunjuk penggunaan pestisida. Jakarta: Penebar Swadaya. 